\title{
On the Boundaries Between Good and Evil: Constructing Multiple Moralities in China
}

\section{ROBERT P. WELLER AND KEPING WU ${ }^{1}$}

This essay discusses three contrasting versions of the relationship between good and evil in contemporary China: a spirit medium who maneuvers between them, a charismatic Christian group that forges an identity by defending the border between them, and an official state and religious discourse of banal goodness and universal love that seeks to annihilate evil. Each defines good and evil differently, but more importantly, each imagines the nature of the boundary itself differently - as permeable and negotiable, clear and defensible, or simply intolerable. These varied conceptions help to shape alternate views of empathy, pluralism, and the problem of how to live with otherness.

Zhe man mu de shan, tian na, duomo pingyong! Ere, duomo xuyao linggan! 这满 目的善, 天哪, 多么平庸! 而恶, 多么需要灵感! [This goodness you see everywhere, good heavens, how banal it is! And evil, how it needs some inspiration!]

—Xi Chuan 西川 (1999)

オ demon, heard a Christian preacher relate her battles with ghosts, and received social media messages implying that passengers in an evil cult were responsible for a lost Malaysia Airlines plane. This essay explores these three contrasting stories of good and evil in contemporary China to show how they foster multiple moralities. We will argue that the key differences among these concurrent moralities arise from the fundamentally different kinds of boundaries they draw between good and evil, rather than simply from a choice among varying goods and evils. Some boundaries are permeable and mediated; others draw clear lines of differentiation. Still other systems seek only to dissolve boundaries, leaving no room for any alternative. Reconsidering the boundaries between good and evil in this way can help us think about ways to deal with people who are truly different from us, that is, about problems of empathy and pluralism.

We often think of boundaries as clear lines of separation. The political boundaries of nation-states are intended to work this way, as are the boundaries created by legal codes. Mary Douglas's (1966) famous discussion of the prohibitions of Leviticus, for example, argued that kosher laws condemned areas of ambiguity between categories as unclean,

Robert P. Weller (rpweller@bu.edu) is Professor of Anthropology and Research Associate in the Institute for Culture, Religion and World Affairs at Boston University.

Keping Wu (kepingwu@gmail.com) is Associate Professor of Anthropology at Sun Yat-sen University.

${ }^{1}$ The order of authors' names is alphabetical, and authorship should be considered equal. 
and thus clarified and solidified boundaries. Nevertheless, other ways of thinking about boundaries can be just as important. Seligman and Weller $(2012,5)$ thus explore how humans "create boundaries and transcend them at the same time" and argue that while categories are important means through which we understand the world, ambiguities allow us to live together despite differences created by boundaries.

Rituals, for example, always cross and recross boundaries, most obviously between the sacred and profane, and between ritual time and ordinary time. They work more like cell walls than brick walls, allowing and encouraging movement across the boundaries that they define. This ability to cross over the separations of self, ethnicity, or nation is a key reason why some early Confucian texts emphasized the critical role of ritual in creating social order. ${ }^{2}$ Still other kinds of boundaries can instead be fuzzy and open, leaving wide space for ambiguity or contextual renegotiation. Such alternate understandings of boundaries are especially important for thinking about the relation between self and other because they deal differently with issues of ambiguity and difference (Seligman and Weller 2012). Each of the three cases we discuss here imagines the boundaries between good and evil (and thus in a sense between self and other) very differently. ${ }^{3}$ That is why we see them as fundamentally alternative moral worlds, even if their various concepts of good and evil overlap.

Two of our cases tie intimately to contemporary life in the booming cities of southern Jiangsu Province, one of China's most developed regions; the third is national, although we will focus to some extent on its implementation in Jiangsu. ${ }^{4}$ The first case was a battle waged between a spirit medium possessed by Sakyamuni Buddha and a monkey demon (houzi jing 猴子精) who had infiltrated a woman's body. The spirit medium's power, as we will discuss, though attributed to the Buddha, comes from his ability to negotiate between good and evil and to harness the power of the evil. The boundaries here are ambiguous and easily crossed. The second case is the story of how a preacher joined the True Jesus Church, a loosely Pentecostal movement she helped bring back to life in one large city in the 1990s. The process for her was an exhausting battle against ghosts and demons (gui 鬼), and similar battles continue to be an important part of the discourse of this group. Here the boundary between good and evil is not permeable, but must be clearly defined in order to consolidate group identity. Finally we will discuss condemnations of "evil cults" (xie jiao 邪教), which have taken place nationally. These condemnations

\footnotetext{
${ }^{2}$ For an example from the Book of Rites, see Puett (2010).

${ }^{3}$ We are using the word "evil" here mostly as a loose and broad translation of the Chinese term xie 邪, because that is the term we heard most often from our informants. Usually translated as "evil" or "heterodox," literal readings of xie include "crooked" and "irregular." It is the opposite of zheng 正, meaning upright or orthodox. There are many other plausible candidates for "evil" in Chinese as well, including bushan 不善 (non-good), zuie 罪恶 (crimes and loathsomeness, Christian “sin"), yinci 淫祠 (immoral temples), and others.

${ }^{4}$ Because of privacy concerns, we will be vague about exact locations and will generally not use real names. The primary field sites include Nanjing, Suzhou, Changzhou, and Changshu, all of which have populations of at least one million. All of the cases and interviews we discuss in detail here occurred in 2013-14, when Weller spent a year doing fieldwork in the region and Wu spent several months. Wu's field research in the region extends back to 2006. Most of this work focused on religion and philanthropy, especially in Buddhism and Christianity. These incidents of evil were an unforeseen benefit of that fieldwork.
} 
occur within a larger discourse of universal, unbounded goodness and love that these groups promote; it has strong affinities with post-Enlightenment ideas of universal values in a world of progress. This talk of generalized love never mentions evil and leaves no apparent space for a boundary around goodness, but evil nevertheless remains out there and must be destroyed to maintain the imagined boundlessness of good. We will turn in this final case briefly to Freud, who discussed (in a rather different context) how ideals of universal love can also drive extreme versions of intoleranceboundaries (and the people on the other side of them) that should be annihilated rather than clarified or crossed.

Talking about multiple sets of good and evil with different kinds of relationships between them reminds us that we need to be careful not to read the particular Western theological history of Evil into every context. There are lots of different evils, each reshaped by the good with which it interacts and by the nature of the boundary around it. Alternative conceptions of the relation between good and evil thus create different moralities. By emphasizing the symbiosis and multiplicity of good and evil, we aim to bypass what some have called the "Durkheimian trap" in current discussions on the anthropology of morality - the argument about whether morality means routinely following a set of social norms or instead means that individuals must consciously choose among conflicting values (Yan 2011b). Yunxiang Yan, for example, describes contemporary China as a place with multiple ethical discourses and moral practices that coexist in tension and contradiction. Even though he sees a general shift toward an individualistic ethics of rights and self-development, he argues that the older forms still operate as deep currents (Yan 2011a, 70).

Similarly, the three versions of good and evil we discuss are present concomitantly, creating a dynamic field. We hope to make a stronger point, however, that the nature of the boundaries drawn between them may be more significant than the content of the various ethical traditions. A focus on the boundary itself helps clarify how morality depends on more than just the choices we make: it depends on how we conceptualize the relationship between good and evil rather than just the specific content of the categories. In taking this approach, we are drawing on recent literature in the anthropology of morality that leaves space for multiple moralities, but our emphasis on the nature of the boundaries is quite different from that literature's focus on freedom and agency (Laidlaw 2014) and on the "morality of choice" in times of cultural change (Robbins 2007).

It is not possible in this article to discuss the modern history of ethical change in China; the situation is so complex as to defy easy summary. It is tempting to suggest an evolution from the sort of relational morality which Fei Xiaotong (1992) suggested was traditionally Chinese, to the class-based love (and hate) of the Maoist period, to a more universalizing discourse of individual-based ethics today. Such a story indeed captures part of the picture in China today, and we will expand on it in the section about love below. Yet it greatly underestimates the complexity of ethical thought both now and historically in China. Older moralities continued through the Maoist period (see Yan 2011a), but they also constantly adapted. Thus all three versions of goodness and evil that we discuss are fully modern in the sense that they continue to make sense of contemporary experience for people. Nevertheless, as we will discuss below, our focus on the nature of the boundary suggests that the one with the least space for tolerance and empathy may be 
the most universalizing version of goodness, which has tended to dominate the discourse of "modern" morality and philanthropy in China and elsewhere.

\section{Buddha Battles a Monkey Demon}

Chen is an “incense leader" (xiangtou 香头) with a large network of followers and an imposing reputation that includes rumors of ties to both the police and less savory social elements. The term "incense leader" in this region refers to people who can take one or more of three different roles: they mediate relations between clients and religious specialists by arranging major household rituals like funerals, they arrange pilgrimages to important temples, and they act as spirit mediums. Chen performs all three roles, and is thus a mediator between different kinds of religious actors, between temples, and between humans and the spirit world. He lives in a large, elaborate mansion at the expanding edge of the city - an area that was mostly agricultural a decade earlier. From the outside there are no obvious religious markers except a large pile of ash from the recent burning of spirit money. His main shrine is in a steel-sided building to the right of the house; with the doors closed it appears to be a garage.

Inside, however, the shrine centers on an altar to Sakyamuni and has the usual paraphernalia of a temple. On a bright spring morning in 2014, he sat in the large leather chair behind the desk to the right of the altar, while one of us chatted with him and various clients who wandered in. ${ }^{5}$ Chen's story is not unusual for a spirit medium. He was plagued with illness from when he was about eight years old until Sakyamuni and Guanyin began speaking to him when he was sixteen. Those gods, he explained, look nothing like what we would expect from the usual paintings and statues. Sakyamuni in particular bears little resemblance to the calm and kindly images we usually see. He is actually enormous and very dark, with bare feet. Most striking is a band of blackness all around his eyes, which Chen kept emphasizing. This is a Buddha to inspire awe in Rudolf Otto's sense: fear as much as love, dread as much as respect (Otto 1958). Such power is what lets Chen do battle with demonic spirits.

As we were talking, a tall, gaunt woman walked in without a word and began worshiping in front of the altar. Chen quickly shooed her out to stand alone in the courtyard in front of the building while he continued our conversation. At one point he said, "You know, there are really a lot of evil things (xie dongxi 邪东西) in the world right now. It hasn't been this bad for maybe twelve or thirteen years." When asked what he meant by "evil things," he frowned and silently pointed at the woman standing outside. Like many of his clients, she had no social ties to Chen before she got sick. She had just heard of his reputation and came to see him. He thus treated her without knowing much about her life. Cured clients sometimes establish stronger ties with Chen and now form a network of several dozen people. Some of them become his formal disciples. This woman, however, had not maintained the tie and so was not well known to Chen or

\footnotetext{
${ }^{5}$ We are grateful to the anthropologist Yang Der-Ruey for introducing us to Chen. He was also present on this occasion. Weller spent time with Chen and several of his disciples after this, and again during a visit in 2015. Both authors have also spent much longer periods of time with other incense leaders in the region.
} 
to the various members of his network who were lounging in the temple at this point. There was also no extended verbal interaction with her before or during the session.

Chen kept interrupting our conversation to talk on his cell phone. During one of these calls, his body seemed to undergo a subtle change, and one of his hands clenched into a fist, gently shaking in the air. He beckoned the woman back in and gestured that she should worship again at the altar. As she did this, Chen continued to sit in his chair, slouched down in a mild trance. His hands formed various esoteric mudras, not quickly, but with a calm patience. Occasionally he flicked his thumb against one of his finger joints, just as Daoist priests do to invoke various divine generals that they control. At several points his lips moved as he uttered a silent mantra. As this went on, the woman began to emit occasional odd belches. And then she wept. Sometimes she did both at once as the episodes of crying and belching waxed and waned.

After a while, Chen stood up from his chair and walked over to her. With his hand formed into a sword mudra, he pressed his fingers onto her forehead between her eyes. He then touched the sword-hand to the very top of her head. Her sobbing grew louder as he drew magical talismans ( $f u$ 符) in the air in front of her. When he placed his whole hand down on the top of her head, her entire body began to shake and quiver. He pressed the attack further, now with fingers at both her temples. With this, she spoke for the first time. Or perhaps not she but "it," the evil thing that had hold of her. It yelled in a hoarse voice full of anger: "I am only a little weaker than you! I will be back to fight you again!" This was one of the only verbalized moments in the session.

The battle gradually calmed down, and Chen then escorted the woman-now no longer crying or belching - to a smaller altar inside his house to recite a simple Buddhist text on her own. He soon rejoined us and explained that she was possessed by an extremely powerful monkey demon. "It could speak human language," he said. "Do you have any idea how long they have to cultivate themselves to master that? At least 3,000 years!"

Monkey demons and similar animal spirits are a staple for mediums like Chen, who can be found throughout the region. Fox spirits (huli jing 狐狸精) are the best known, but Chen has cured even very unusual ones like a fish and a toad demon (see Kang 2005). Such mediums use their power to subdue and expel the evil thing possessing the victim. Control of such great power, of course, is itself dangerous, and the line between evil and good can sometimes blur-recall the gargantuan scale and darkly shaded eyes of Chen's Sakyamuni.

Similar to shamans in Siberia and witcheraft in Cameroon, sometimes "evil things" in China are not simply exorcised, but can be tamed or "canalized and used for constructive aims in order to make society work” (Geschiere 1997, 291). The spiritual entourages who surround major deities in China often look frightening, with bulging eyes and grimacing faces in unnatural colors. This is because their origins are in fact demonic. They serve these gods only because the gods have overpowered them and rechanneled them for better purposes. Many deities themselves have hints of evil mixed into their origin stories (Shahar and Weller 1996).

In this context, none is better known than Sun Wukong 孙悟空, who was made famous throughout China in the popular Ming Dynasty novel Journey to the West. He is best known in English through the translation of his name simply as Monkey. Born from a stone, he is a nature spirit whose origins are very similar to the spirit that Chen 
fought. Sun Wukong gradually cultivated his powers until he became more powerful than all the forces of the gods. In the novel, the monkey is a magical trickster who wreaks utter havoc in heaven until the Jade Emperor has to ask Sakyamuni to intervene. Ultimately controlled by the Buddha, Sun Wukong eventually helps bring Buddhist sutras to China-the trickster ultimately comes to serve the dharma.

This character had complex origins, but is in part a novelistic translation of the animal spirits that occur across China. ${ }^{6}$ Like Sun Wukong, the evil monkey spirit battling Chen began by cultivating himself alone in the mountains. Demons like this one increase their powers by devouring the fundamental life energy (yuan q $i$ 元气) of their victims. As Chen explained, if left untreated, these victims invariably die a wasting death. Usually such demons (unlike Sun Wukong), if they do not kill their hosts, flee back to the mountains after being exorcised, cultivating themselves ever further. This is exactly what our monkey demon will do. Because he had not fully defeated the demon while we were there, Chen undertook a more complicated and dangerous ritual later (too dangerous for us to witness). This, he reported, was fully successful. The woman was cured, but the monkey, he felt sure, would eventually be back.

Mediums like Chen move across the edges of the worlds of awe-inspiring gods, murderous animal spirits, and human society. These worlds intertwine to the extent that it can sometimes be difficult to extricate one from the other. For incense leaders, the boundary between good and evil is permeable; mediums like Chen have to be able to cross it, and it is possible for spirits and people to move largely from one side to the other. For example, part of Chen's responsibility as a spiritual mediator is to arrange pilgrimages for his followers. Every year he makes sure to include at least one trip to Shangfang Mountain (Shangfang Shan 上方山), which is also in southern Jiangsu. This site is especially famous for its temple to Taimu 太母, the Great Mother. She was said to be the mother of the Wutong 五通 deities, who have long been among the most important gods throughout this region. Yet the Wutong themselves have a past that was clearly demonic, and the entire cult was often attacked by Confucian scholars and officials as something evil. ${ }^{7}$ According to Chen, Taimu herself is a spider demon, by far the most powerful such spirit in the entire region. Not everyone understands her as a spider, but another one of her spirit mediums elsewhere in the region completely agreed, saying that she feels spiders crawling up and down her body when Taimu possesses her. Why take people on pilgrimages there? Chen explains that it is because Shangfang Mountain is the origin for most of the "evil things" who attack the people he treats. Going to her is like going straight to the biggest gangster of all in order to get the petty hoodlums to back off.

Shangfang Mountain is also the center for the practice of "taking out dark loans" (jie yin zhai 借阴债). These are enormous favors that one can ask from Taimu's children, the Wutong (see von Glahn 2004, 229-32). Unlike the practice at most temples, where gods will grant only morally upright requests, these dark loans can be for anything at all, regardless of morality. Such loans are more like the ones available from gangsters than from friends, however-the interest rate is high and the punishment for failing to repay is dire. In many cases, the repayment is said to come at the expense of the

\footnotetext{
${ }^{6}$ For one line of origin, and some discussion of others, see Shahar (1992).

${ }^{7}$ There is a significant scholarly literature on the Wutong. In English, see Guo (2003), Szonyi (1997), and von Glahn (2004).
} 
borrower's children, whose health and fate are mortally damaged as a result. ${ }^{8}$ These stories long predate the modern period, and it should not surprise us that this talk of the amorality of loans, money, and markets in general thrived in this area that had long been the commercial heartland of China (see, e.g., Kuhn 1992).

These stories cannot be reduced to a simple critique of the market, however. The "evil things" that underlie them arise from stories about selfish individualism rather than directly about markets and commodities. The monkey demon, for example, gained its power through intensive self-cultivation (xiuxing 修行). Cultivation in China is generally very highly valued as a way of becoming a better person, whether pursued through meditation, practicing calligraphy, or studying the Confucian classics. Animal spirits like our monkey are pursuing a very similar route, but rather than using it to make themselves better members of a structured social community, they are sacrificing the community to fortify their own individual power. The problem is not cultivation itself, but rather the destruction of social networks and the abrupt ending of patrilines (just as in taking out dark loans) for the sake of the isolated individual. Those who benefit monetarily at the expense of their offspring's fortune by worshiping the Wutong are extremely selfish individuals who destroy the lineage and the community. On the other hand, incense leaders like Chen are nodes in the local social community, both holding together and actively creating those networks.

How does one balance the demands of these social networks against the need to pursue one's own interests? This is never an easy issue, and a thriving market economy with its opportunities for profit makes it even more difficult. On the one hand, we have Macfarlane's $(1985,74)$ suggestion that a money economy is "fatally entwined with an inability to distinguish good and evil," because the market creates an amoral world in which such judgments are impossible. On the other, there is Taussig's (1980) well-known argument about Colombian devil worship rumors, which sees rather similar stories of evil as critiques of capitalism from the viewpoint of a prior mode of production.

Neither of these classic arguments works very smoothly for this case, however. Unlike Macfarlane's claim, an interaction between good and evil remains vibrant. Unlike Taussig's argument, we have seen a similar dynamic of good and evil at play in this region of China for centuries. In this area of China, urbanization and relocation have been taking place over long periods, and a commercial economy was already strongly developed by the sixteenth century. We do not have a battle between older and newer modes of production. We do, however, witness a tension that has remained permanently unresolved and continues to make sense of experience even in the rapidly changing conditions of today. It tells us that power is always two-edged, that finding a path in the world requires negotiating good and evil, and that the potential for evil always lurks, not just over our shoulders but in our own desires. Just as importantly, this kind of permeable boundary requires people to live with interactions between good and evil, between one's own people and those powers that are fundamentally different and sometimes opposed to us. That is, it requires people to relate

${ }^{8}$ Such stories are remarkably similar to the Eighteen Lords temple in 1980s Taiwan, which one of us has documented elsewhere (Weller 1994). 
pluralistically, always open to movement across the boundary, so that a stone monkey spirit can become a protector of the dharma, and a spirit medium healer can make offerings to the mother of evil.

\section{Ghosts AND The Holy SpIRIT}

Preacher Liu became a Christian in the early 1980s. ${ }^{9}$ A decade later she was running a Presbyterian house church with about thirty or forty followers. By the early 1990s, however, she began to feel some dissatisfaction. As a result, she joined a group of about a dozen seminary students on a trip to visit a preacher they had heard about in Fujian. As it turned out, he was a leader of the True Jesus Church (Zhen Yesu Jiao 真耶稣教), a form of indigenous charismatic Christianity that began in north China in 1917 as part of the rapid global spread of the Pentecostal movement at the time. ${ }^{10}$ Not willing to join the officially sanctioned Three Self Church after the Communist revolution, it had not survived even underground in her home city. Liu herself knew nothing about the church at the time, but shared in the general unhappiness of some Christians in the early 1990s with an official church that had been very slow to change with the times. Note that this was, in her mind, completely an act of religious searching with no political implications. True Jesus is not much liked by the official Protestant church in China, but it has been tolerated in Liu's city since it reopened. It is registered with the Religious Affairs Bureau and operates legally and openly.

The group arrived in Fujian, and the True Jesus preacher there explained the Bible in ways Liu had never heard before. The Presbyterians, she said, had always condemned True Jesus as an evil cult, so she had never before paid attention to it. She went to bed that night feeling that perhaps finally she was beginning to see what was True, perhaps she had found her true home.

And that is when the ghosts attacked. Male and female ghosts, ghosts of the night and of the day, monstrous and mischievous ghosts, she battled them day after day. The first came at 2:15 in the morning, with the sort of music, she explained, that people hear in traditional Chinese ghost stories, right before the fox spirit shows up. ${ }^{11}$ As she told it:

I wanted to sleep, but as soon as I heard that music I didn't dare.... The door opened ... and what sort of thing came in? It was like a man, but so tall [gesturing very high with her hand], with a human head and an animal face! And his whole body was covered in fur... Then I got up to my knees. I was kneeling and he was standing. We were eye-to-eye.... Then with my hands I started to pray, you know, "In Jesus's name bind up this devil," that kind of thing. Those

\footnotetext{
${ }^{9}$ Both authors visited her church separately on numerous occasions in 2014 . We interviewed other members of the staff and took part in multiple services. Most of the quotes here come from a single long interview, but the broader analysis draws on the other visits as well.

${ }^{10}$ On the history of the True Jesus Church, see Inouye (2011) and Lian (2010).

${ }^{11}$ She referred explicitly to the most famous collection of ghost stories in China-Liaozhai zhiyi 聊斋志异, translated as Strange stories from a Chinese studio, written in the early Qing dynasty by $\mathrm{Pu}$ Songling. Liu almost always used the traditional term for ghost rather than more usual Christian terminology.
} 
outside religions (wai jiao 外教), the Presbyterians, that kind of prayer. And I jabbed at his nose. His eyes were really big, and he hated me, and I hated him. He wanted to devour me and I wanted to devour him, that's how it felt... And then he left.

Although this first ghost left, other ghosts constantly hounded her, day and night. Still, she did not admit the problem to the others. "I wasn't embarrassed exactly, but I thought that since I have been a Christian for so long, how can I be telling people about seeing ghosts? They would think there was something wrong with my faith. How can you see ghosts after being a Christian for more than a decade?"

She went on to explain how the True Jesus people at this church prayed by speaking in tongues (lingyan 灵言) every evening. She admired their explanations of it, but she could not do it. She had always prayed consciously (wuxing daogao 悟性裙告) and silently as a Presbyterian, but this was like a "torrential flood crashing out of the mountains, it just completely knocked you over." She could not manage this kind of prayer at all. Often she did not dare to join the prayer group. Once, when she did, she felt her hand starting to shake as the Holy Spirit moved her, but it frightened her and she grasped it with the other hand until the shaking stopped. Meanwhile, ghosts continued to assail her. Finally, after three days and nights of this, she could no longer bear the constant struggle and lack of sleep:

I said I have to go home, and they asked why... I explained that I had already been battling the ghosts for days. I wanted to go; if I didn't go, I wasn't sure I could continue living. Then they led me in prayer. There, on the third day at the same time, God ordered the Devil very clearly to let me go. I heard the ghost music again, and I said, “Oh heavens, it’s back again, in the daylight!" It was the same ghost from three days before.... At that time I had hated him so much, and I thought, "I already defeated you once. I took a big bite out of you!" But whatever, I was going all out to fight him again.... He hated me and wanted my death; I hated him and wanted his death. I jabbed at his nose, over and over ... but I couldn't hit him. Then he looked at me, oh, maybe for a minute, and then his_-it wasn't really a hand but a claw_clutched at my head. He pulled off a fishnet. He pulled it right off my head and left. He had spread it over my head, three days earlier he had put it there, and now three days later he took it away. He was gone.... I fainted.

While unconscious, she felt herself falling deep down, crying out to the Lord that she had been wrong, that she wanted to be baptized in the True Jesus Church (which does full immersion adult baptism and does not recognize the baptism of other churches); she did not want to die but wanted another chance. When she came to, the local preacher told her how to invite the Holy Spirit in. She went upstairs to pray, explaining to the Lord that if He did not allow the Holy Spirit to come down she would have to fight the ghosts again, and she would surely die. She then knelt down to pray in the True Jesus fashion, confessing her sins to God and saying "Hallelujah!" On the fourth hallelujah, she suddenly heard herself speaking an unknown language. 
It sounded like Cantonese or some sort of weird dialect. It sounded so odd. Who was talking? It sounded like birds tweeting, bird language [a common way in China to make fun of southern dialects], that's how I felt. I didn't understand about receiving the Holy Spirit. It scared me to death.... I didn't dare open my eyes.... I didn't know I had received the Holy Spirit. I thought, this is horrible. Have I turned into a bird? These sounds were really coming from me. Oh no, I must really be a bird and I could never go home again. I kept my eyes tightly closed, because I was afraid that if I opened them I would see I really was a bird.... Finally, with my eyes closed, I felt my head. Was it really a human head or a bird head? And it didn't feel like my head! This was the Holy Spirit rebuking me. What bird language?! You have received the Holy Spirit! You have sinned so much, I love you so much, the Holy Spirit came to rebuke me.

The ghosts never returned. Liu was baptized into the True Jesus Church, and returned home to tell her Presbyterian congregation that hers would now be a True Jesus church. Most of them stayed with her, and the group reports that they have baptized about 1,800 people in this city in the two decades since then.

Evil here is necessary, although in quite a different way from the world of the spirit medium and the monkey demon. Both evils are life threatening; both even look alike to some extent, part human and part animal. Yet, the kinds of boundaries they draw work in very different ways. Chen's evil and good can morph into each other, as we see in his worship of Taimu, the mother of evil, and perhaps even in the frightening visage of his Sakyamuni Buddha. It is never ultimately defeated, but rather compromised with. In a way, Chen's power of the good grows as the power of evil gets stronger. The border between them is permanently ambiguous and fuzzy. If the evil completely disappeared, the existence of good would become unnecessary. An absolute boundary, however, marks off Liu's evil, and drives one to the absolute good of God.

Liu's True Jesus experience was very much about creating integration, for her self as an individual psyche and for the church more broadly. Evil always pushes on them from the outside, threatening dissolution of integrity. We can see it clearly in Liu's own personal sense of integration, which almost collapsed completely during her ordeal. Recall her joking reference to "bird language," which quickly became no joke at all as she reached to touch her head, sure that she herself was no longer human. And recall the rapidly shifting point of view at this crisis point: "You have sinned so much, I love you so much, the Holy Spirit came to rebuke me." She reintegrates only by finally recognizing and accepting the gift of the Holy Spirit. In the same way, the church itself maintains integrity by fighting the evil that is always trying to pull its followers away from the Truth.

For instance, Liu told us that they have special services for people who are unable to speak in tongues. The Spirit descends, she said, only to people without sin. Those who cannot speak in tongues (including, of course, most other kinds of Christians) are thus sinners, seduced by evil. On another occasion, an older woman came to ask Liu why she kept hearing strange whispers and noises, like windows rattling. "Don't worry," said Liu, “it’s just devils (mogui 魔鬼).... Ignore them.... Don't be afraid of them and keep reading the Bible and praying to God." When she preached later that day, the message was similar, but much more dire. She spoke of things that Christians should 
avoid, including harboring any doubts about their belief. Once you have faith, she warned, members of your family might die because devils attack them. The devils are trying to compete with God and make people afraid to continue in the Church. Even as relatives die, people must maintain their faith. There is a clear sense of us versus the outside world, good versus evil, Christ versus the Devil. The devils are always eager to snatch human bodies, but the battle always ends in the triumph of the good. We thus have a strong boundary between believers and the evil beyond, a boundary defended by belief, prayer, and the Bible. This is very common among converted Christian communities that often treat all the indigenous spirits as evil (Meyer 1999; Robbins 2004) and thus define Christian identity against such evils. But the evils still need to exist. They keep coming back in the forms of rituals, dreams, and personal battles such as Liu's. ${ }^{12}$

Chen's spirit medium network, however, seems far less interested in integration. After all, a self that is sometimes Chen and sometimes the Buddha is not particularly pursuing unity. The same is true for his cured disciples, who have not been healed by becoming psychically integrated, but rather by learning to harness the alterity within them. In battling the evil spirits, the evil becomes familiar and tamed. It is like a cold that happens from time to time but can never be completely cured; the occasional attacks actually boost one's immune system. The key is not to crush evil completely but to control it and prevent it from doing harm, always cultivating one's own power, which is only enhanced by proximity to evil.

Liu's church, on the other hand, shapes a tightly bounded group, surrounded by the sharp borders of baptism, and threatened by the non-belief that encircles them. Both the church and the spirit medium network need evil in order to pursue good, but they are structured in utterly different ways—not just different in how they guard their boundaries, but in how they perceive the nature of an individual, of a group, and of boundaries themselves.

\section{Evil Cults, Love, and the Banal Good}

It was actually love that drove us to evil. Not hot, romantic love for a man or a woman, but lukewarm, vanilla love for everyone in general and no one in particular, a love for the people but not for a person. We had been working for several years on social constructions of the good in China, especially as seen through religious philanthropy. Everywhere we turned, people spoke to us about love-from the Amity Foundation (the largest Protestant NGO in China) to preachers in small churches, from the globally powerful Buddhist group Tzu Chi (based in Taiwan but now active in China as well) to private conversations with monks. Volunteers and donors, government officials and Communist Party cadres all told us about how people should be driven by love:

\footnotetext{
${ }^{12}$ Our analysis highlights the religious and personal contexts of evil in this form of Christianity, rather than the possible political implications. This is consistent with their own view of themselves. As another one of their preachers said, "We don't really care about the state. We only care about eternity." This is similar to the conclusions reached in Inouye's (2011) dissertation about the True Jesus Church.
} 
universal love (jian ai 兼爱), broad love (bo ai 博爱), big love (da ai 大爱). Such a love is quite different from both Confucian and high socialist versions of the idea (Lee 2007). It is, as Yunxiang Yan $(2009,22)$ notes, based on a "new individual morality of rights and self-realization."

There appears to be no evil in this version of the good. Poverty, illness, and disaster are unfortunate, of course, but those are merely problems to be ameliorated. They are not evils themselves, or even symptoms of an underlying evil. This "good" is banal-a cliché that appears flat and even for everyone, everywhere. Quite unlike the spirit medium or the True Jesus preacher, there is no boundary at all around this kind of imagined goodness. It spreads everywhere, universally, without distinction. It is banal in the same sense that Eichmann's evil was banal for Hannah Arendt, through its utter reduction to repetition "word for word [of] the same stock phrases and self-invented clichés" (Arendt 2006, 49). That is why our various encounters with evil in the field seemed so refreshing: they countered the reduction of goodness to a generic and flat universal, endlessly invoked but lacking specific content. They provide an escape from the hegemony of this kind of boundless good and allow alternative ways of dealing with differences.

In its religious policy, the Chinese government became gradually more tolerant of a religious discourse of love in the 1980s and 1990s, and now often uses the stock phrases of such "love" language itself. The success of such merging of discursive worlds was clear when Ye Xiaowen, the former head of the State Administration for Religious Affairs (SARA), praised the "positive attitudes" of religions such as the "humanistic Buddhism" promoted by Zhao Puchu, the then lay Buddhist leader of the Buddhist Association of China (BAC) and the "service-oriented and ethical" Christianity promoted by the late Bishop K. H. Ting, first chairperson of the Three Self Patriotic Movement, president of the China Christian Council, and founder of the Amity Foundation (Ye 2007, 194).

In 2013, when we were doing fieldwork in Jiangsu, many religious groups quoted the current president Xi Jinping's speech on “positive energy” (zheng nengliang 正能量) to discuss their engagement in charitable affairs. Thus among religious groups, there seems to be an urge to purify themselves from the negative past of religions and remodel themselves on something positive-with love being the ultimate positive energy. Bishop Ting had long put love at the center of Chinese Christian theology. According to Wielander $(2013,49)$, “The central tenet of [Ting's] theology was the move to a non-denominational Chinese church built on the core message that God is Love."13 This replacing of Christianity's millenarian message with love has been applauded by the Chinese government as well (Wang 2010, 394).

Parallel to Ting, the Venerable Cheng Yen (Zhengyan) of the global Buddhist group Tzu Chi has been promoting “Spreading Love” (aisa 爱酒) and naming all its large-scale missions as "Da'ai" (Big Love) since 2000. Instead of loving a small circle of family or friends, one should love all living things. Other Buddhist groups now also frequently speak of love as a fundamental value, although the term occurs very rarely in Buddhist

\footnotetext{
${ }^{13}$ Wielander (2013, 51-53) further shows that the CCP's extensive official writings on harmonious society often refer to Western civilization, and specifically to Christian universal love, as one of the idea's many sources, and they reinterpret Confucian ren 仁 ("benevolence") as airen 爱人 ("loving people").
} 
sutras and even sounds counterintuitive to the Buddhist idea of nonattachment. This discourse of love has become dominant across religious and national lines since the 1980s.

The two of us organized several interdenominational focus groups on religious philanthropy. ${ }^{14}$ When we asked participants at one of them their motivations for social service provision, the representative from that city's YMCA said that the spirit of universal love (bo ai 博爱) in Christianity is the key: “It's important to show an inclusive love." During the same event, Pastor Li from the official Three Self Protestant Church also put love at the core of their message. An employee at a Buddhist-inspired vegetarian restaurant gave us a brochure called "guarding our home with love" (yong ai shouhu jiayuan 用爱守护家园), and explained that the greatest love was not killing (animals). Using love as the dominant discourse makes it possible for these groups to reach the general public, instead of being restricted by specific theological terms that are only familiar to insiders. After all, who is going to reject love? Love enables the religious groups to dialogue on the same platform with other parties engaged in social service provision: the state and the NGOs. It lets them claim common ground with one another, pointing to their common love without highlighting their deep theological and ideological differences; it is reduced to banality, which is exactly what makes it so useful.

Love is not only used in the philanthropic discourses of religions. In July 2014, one of us attended a True Jesus prayer group for college students who were not members of the church. The preacher spoke about love, from small love to big love and God's love. This was different from the tone during regular True Jesus services, and the staff explained later that the talk of love (and the avoidance of speaking in tongues) was to appeal to an audience that did not yet believe-the vagueness of love was what made it useful. During the event, one young woman offered her testimonial in tears. Not shed in sadness, she said, but because the discussion of love had recalled the love of her parents for her, which she had ignored for so long, until she found Jesus. At the end, several of us were also given little cross-shaped key chains that said, in English and Chinese, “CROSS; Love never fails” ( $a$ i shi yong bu zhixi 爱是永不止息). They used "love" on this occasion exactly because it could appeal to anyone, though it revealed little of the heart of this specific group. Talk of evil, like speaking in tongues, was reserved for people already committed to this church.

This power of love echoes what Pastor Zhang in Hangzhou told us in May 2014: "Our main service principle is love, Jesus's love.” In Buddhism too, the millenarian aspect of Buddhism was rarely mentioned during our field research. Instead, they emphasized the positive aspect of big love or a loving heart (ai xin 爱心). The positive impact of Buddhism on people's lives was reiterated, through loving animals and loving the environment (being vegetarian), loving oneself (being a more enlightened person), and giving a loving heart to people in need (being a volunteer).

\footnotetext{
${ }^{14}$ Both took place in the spring of 2014, one in Nanjing and one in Shanghai. They were convened jointly by the authors. The group in Nanjing consisted of locally important clerics from four of the recognized religions, all involved in charitable work. There were also leading lay Protestant and Buddhist leaders involved in informal charity. The group in Shanghai was a similar selection of religious leaders from Shanghai and Suzhou, with the addition of some retired Religious Affairs officials. Catholics did not attend either group, probably due to political sensitivities at that moment. There were about a dozen participants in each group.
} 
The beginnings of this discourse of love among religious groups coincided with state efforts in the construction of Socialist morality. During the Cultural Revolution, love was an important value, but should only exist on the basis of class; it could not extend to people like capitalists. In the softening of the 1980s, official Socialist morality began to relax the primacy of class, and we began to see more nationalist love slogans like the ubiquitous "love the country and love the people" (ai zuguo ai renmin 爱祖国爱人民). A religious variation of this first appeared in 1993 in the "Regulations for the Buddhist Association of China"- “love the country and love the religion” (ai guo ai jiao 爱国爱教). By 1996 it had been emulated in the "Regulations for the China Christian Council." This slogan is now repeated dutifully by all five religions at nearly every official religious event. It does not represent a fundamental change in religious attitudes so much as a change in the party-state's ever-widening use of love discourse. As the scope of love has become ever wider and ever more vague, it has created an opportunity for religions to justify themselves in the state's terms while still emphasizing their moral commitment as religions.

This party-based embrace of love infiltrates secular life as well. For instance, a series of Morality Lecture Halls (Daode Jiangtang 道德讲堂) have appeared throughout China since 2012, run by the Propaganda Bureau. One of us was brought to such an occasion in Changzhou (one of southern Jiangsu's larger cities) and given a book of Moral Stories about the "moral heroes" they celebrate at their events every Sunday. One story is called "The Love of an Angel" (Tianshi de A $i$ 天使的爱): Ding Chenli at age eighteen decided to devote herself to leprosy work. She almost gave up after the first day, when she saw and smelled how awful everything was, but the strength of love kept her committed. She wrote: "Love let me find the fulcrum for my work; love let me find the coordinates of human life. I am willing to be love's angel forever, bringing the light of hope to ever more patients" (Changzhou Shi Wenming Ban 2013, 9). Again, in this narrative the evils (of diseases or other misfortune) are pushed aside by the (positive) discourse of love.

Yet evil does exist, even in this view of love-as-everything. This was obvious when the discourse of love was explicitly class-based: people and classes outside the circle of proper love constituted an enemy to be destroyed, and the Cultural Revolution often used the popular religious imagery of demonic evil to describe these enemies. Nevertheless, as we hope to show in the rest of this section, the ever-broadening circles of love in the past few decades also imply a world beyond the love, which can only be stamped out. In religious circles, this has taken the form of attacks on "evil cults."

In comparison to the world with evil (seen, rather differently, in both the spirit medium and the preacher), the world without evil cannot tolerate evil's existence and often tries to eliminate it through even more drastic means than the evil itself-violence, physical or symbolic, in the name of good against evil. In this way, an imagined world without boundaries nevertheless draws new boundaries, all the more insidious for being denied. Thus all the loving talk has not prevented either the state or religious groups from fiercely condemning "evil cults." The state crushing of Falun Gong in 1999 and the new campaign in 2014 against the cult of "Almighty God" (Quanneng Shen 全能神) are examples.

As the leader of SARA, Ye Xiaowen emphasized that cults are not religions and therefore do not enjoy the legal protections of religious groups (Ye 2007, 198-202). In 1999, 
during the aftermath of the Falun Gong demonstrations, the high court first defined evil cults as illegal organizations (Wang 2010, 392). Note that this was only a few years after love had been embraced by all the religions as a slogan. Wang Zuoan, the new head of SARA, reasserted that cults are not religions (Wang 2010, 393) and therefore could be condemned with legitimacy. By creating an illegal category of "evil" cults, the state has been able to condemn the evil unconditionally. This way of pushing "evil" completely out leaves no room for negotiation or coexistence. Unlike the spirit medium and the preacher, who require the continued existence of evil, this vision intends to annihilate "evil," and anything that does not accept the embrace of its love.

The mainstream religious groups, by accepting this banal love, have been just as active in this process. Buddhist groups were among the first to condemn Falun Gong, and used the term "evil cults" before the state adopted it. In 1996, three years before the government launched the full-scale campaign against Falun Gong, the Buddhist Association in Taizhou (Zhejiang Province) published a series of articles in Taizhou Buddhism, denouncing the group as an "evil cult and demonic practice" (xie jiao mo gong 邪教魔功). In early 1998, the Buddhist Association of China officially assessed Falun Gong as “an outside religion with a pretense of Buddhism” ( fu fo wai dao 附佛外 道). With the approval of Zhao Puchu, the chair of BAC, a lay Buddhist published Buddhist Qigong and Falun Gong (Chen 1999), which was the first book-length criticism of the group, appearing a year before the government made its formal announcement. After the central government launched its war against Falun Gong, the other four state-sanctioned religions followed suit and condemned the group in public as an evil cult (Wang 2010, 393-95).

Falun Gong is not the only "evil cult" that is under attack. For instance, during the hype over a missing Malaysian airliner in 2014, many stories circulated in Chinese social media regarding the cause of such a disaster. One of them came to us from a monastic Jiangsu Buddhist source, very much involved in philanthropic goodness, alluding to the connection between the misfortune and a group of Chinese believers on the plane, who had gone on a healing trip to Malaysia held by a controversial Buddhist group called Xinling Famen 心灵法门, led by the Malaysian Chinese Lu Junhong. In 2014, the BAC delivered a message openly calling Xinling Famen "an outside religion under the pretense of Buddhism." When asked what Buddhists consider to be an evil cult, two informants (interviewed separately by each of us; one was a senior nun who had reposted the story about the airliner to social media) said it is when the leader puts himself or herself up as the sacred person, such as Amitabha or the Buddha himself, which should never happen in Buddhism. This coincides with the state definition of a cult as "an illegal organization that uses the name of religion or Qigong to establish and sacralize the leader, create superstitious or evil messages to control its members and harm the society" (Wang 2010, 392).

Some Christians have their own opinions about what a cult is. The mother of a friend of ours has been a member of a family church (in the Little Flock tradition) for decades. She said that all other religions are evil cults, including other kinds of Christianities that do not belong to her tradition. A few minutes later, she clarified by saying that Islam and Buddhism are indeed evil cults, but other kinds of Christianities are only "outside teachings” (wai jiao 外教). Though in the end she used a more sensitive touch to differentiate between evil cults and outside teachings, the boundary is clearly drawn between the 
"good" and "religion" on one side, and evil cults or outside teachings on the other. Many promoters of the ideals of big love and universal goodness are the very ones who also speak aggressively about evil. It seems that with the increasing emphasis on love by all the religions, the gap between good and evil is all the more insurmountable.

Love- the ultimate good and the positive energy — has been embraced by religious groups, the government, and nongovernmental sectors as an all-encompassing and universal value that should appeal to all. When religious groups reach out to nondevotees with their messages of charity and philanthropy, when the state demands religions and its people to show more love toward it and toward one another, and when nongovernmental organizations ask for loving hearts to contribute to the less fortunate of society, helpless animals, and innocent nature, love transcends all boundaries. It is the most powerful discourse and denies refusal. After all, what else except absolute evil rejects such love? Such an evil can only be exterminated. There is no room to tolerate any other visions of possible loves when love (of country, of religion, of humanity) is unbounded and equal for all, everywhere, when it is reduced to banal repetitions of stock phrases. It hardly matters whether such repetitions are done sincerely or cynically; the implications of the discursive world are the same either way.

The world of the spirit medium imagines a localized network for which he can channel and control the inevitable forces of evil. The True Jesus followers instead imagine an embattled island of goodness defined against the evil that pushes against its barricades. For banal goodness, however, there are no acceptable boundaries; society is global and offers no resistance to its continual expansion. When this fantasy is challenged, however, the evil of refusal is absolute unless it can be obliterated-overtaken by love. Such a vision of goodness absorbs or annihilates difference but does not tolerate it. The banal good is not only without content; it also destroys.

That is, by attempting to transcend boundaries, the banal goodness of universal love creates even more boundaries. In Civilization and Its Discontents, Freud (1962, 49) reminds us that "a love that does not discriminate seems to me to forfeit a part of its own value by doing an injustice to its object; and secondly, not all men are worthy of love." In other words, universal love is no longer love. Freud continues, "It is always possible to find together a considerable number of people in love, so long as there are other people left over to receive the manifestations of their aggressiveness" (61). This further points to the dangerous, hegemonic, and even violent aspect of banal love, just as we saw above in the cases where simultaneous emphases on love and the relentless (sometimes violent) condemnation of evil coexist in the same religious and government bodies. A love-filled world traps us in the goodness that has no room for evil, and where evil must thus be permanently destroyed. This most "modern" of outlooks may thus be the one least able to accept the existence of evil, and thus of genuine difference.

\section{Concluding Thoughts}

All three cases are inseparable from the experiences of people in southern Jiangsu, who live in a strongly market-oriented and consumerist economy, surrounded by a highly urbanized environment, and tied to global media trends. All of them call on ideas with very long histories in China (animal spirits, ghosts, evil cults), but understood only in 
relation to contemporary events. That is, none of our cases pits tradition against modernity. All three goods and evils make sense of the contemporary world through available resources, but they do so differently.

The spirit medium Chen is a literal mediator-between humans and spirits of course, but more importantly between good and evil. He stands at the crossroads, not just channeling the power of gods to control "evil things," but also making offerings to the goddess at the heart of evil. Great power of any kind has the potential for both good and evil; it is frightening. In this image of good and evil, the boundary between them is ambiguous and shifting. Evil here appears as the self-maximizing individual, both in the image of the cultivating monkey demon and of the "dark loans" one could get at Shangfang Mountain. Yet, as we have argued, this is not the critique of the market that Taussig (1980) sees in Colombian devil worship, especially in this region with many centuries of a thriving commodity economy.

The medium's boundary is not stark or absolute, but negotiable and blurred. The goal is not to demolish evil forever, but to make one's peace with its necessity. It is a rejection of the banal love story, or at least a complete alternative to it, because it recognizes the need to deal with evil daily, to respect its strength while keeping it under control. By the same token, we might say that evil also keeps the good in check, never allowing the possibility that it could become a total world of goodness, in which the good can only be banal because it has no more evil. In this view, the past is not more moral than the present, and evil is not less moral than the forces harnessing it.

The True Jesus preacher, on the other hand, is not so much mediating as differentiating. For her, as for many in her congregation, the demarcation and separation from evil is a daily necessity. The battle against evil allows them to integrate internally, both as individuals and as a group. This is, however, also what makes the state nervous about them. The state and the Three Self Protestant movement it sponsors want to rid Chinese Christians of denominations and unite them under the big banner of love theology. It is the battle against evil that marks the True Jesus Church's separateness from "outside religions," including other Christians. Recall that the ghosts were not so much trying to attack Liu's Christianity as her conversion to True Jesus practices. Had they been victorious, she would still be a Presbyterian.

The True Jesus Church differentiates from evil by constantly recognizing it; evil can never be denied or ignored. For them good and evil remain connected, although in a very different way from the spirit medium group. The ambiguous boundary in Chen's practice is here instead a sharply drawn divide, which must constantly be faced. This resonates with some other Christian cases, for instance as Harris (2006) reports from highland Bolivia, where converts live in fear of vengeance from the ancestors they no longer worship. By remaining in sight, these dangerous outside forces allow the group to define itself clearly. Liu and her True Jesus followers demarcate the boundary; they probe it, actively feel its presence, and reinforce it constantly. To a certain degree, parallels can be found in some underground churches' attitude toward the Chinese state, which for them constitutes the evil. The existence of evil is necessary for the groups' legitimacy as the truer church, in contrast to the state-sanctioned church. Again, the evil defines the good. One cannot make a moral decision without consideration of evil.

Only the discourse of banal love makes no direct mention of evil—there appears to be no boundary at all, just the endless expanse of banal love. This infinite love without evil 
may be the result of two interrelated processes. One is the post-Enlightenment rise of the idea that human beings are autonomous individuals, each equal to the other and thus fundamentally identical to each other. Differences become irrelevant or private. These ideas evolved toward a concept of universal philanthropy, especially during the paleo-liberal heyday of the laissez-faire nineteenth century. During this period, many North American and European Christian congregations undertook broad charitable projects for the first time, and we saw the beginnings of international NGOs like the Red Cross, which are now so important. This shift from private charity (love of one's own neighbors or social groups) to public philanthropy (love for all mankind) has happened in China as well, especially beginning in the 1990s. It is no coincidence that the newly expanded role for charity correlates with the state's step back from total welfare responsibility, and with its broadened discourse of love. ${ }^{15}$ The expansion of charity has encouraged a love for all under an umbrella of goodness so universal that it leaves no room for genuine otherness, for the evil that cannot be loved.

The second process is the Chinese state's post-Reform need to find a discursive field that everyone can share. "Love" and "goodness" are ideal for this, especially when they become reduced to formulas so empty that everyone can repeat them while papering over their real differences. For instance, we asked a focus group of religious leaders whether the "good" that each of them pursued was the same as the others. This was initially greeted with bafflement-of course it was the same, good is good. But when we asked more specifically whether the Christians thought releasing captive animals counted as doing good, or asked Buddhists whether saving souls counted as good, our informants quickly parted ways. Slogans like "love the country, love the religion," endlessly repeated, make everyone sound the same, but cover over their very real differences. This is the banality of good: a good without evil, a good reduced to endless reiterations of a few stock phrases.

As we have discussed, though, evil still lurks unseen in the gaps left by this discourse of banal love, even if religious leaders are simply repeating this discourse to curry political favor. Perhaps Freud was right that the bigger the embrace of universal love, the greater the potential for hate of that which stands beyond its grasp. That is probably why the Chinese state has recently become ever more strident in attacking terrorism or cults, while pouring out love through constant morality campaigns. Here there is no way to cross the boundary, no way to build a bridge. It is as if the pathway between good and evil—so vital, in different ways, to the spirit medium and the preacher-had become blocked. The invisible boundary of love is absolute exactly because it is denied: we love each other and bomb the terrorists; religions do "good" and annihilate "evil cults."

These cases show the incompleteness of the post-Enlightenment project of boundaryless equality. ${ }^{16}$ In part, boundaries show up after all, but in an insidious way because this image can no longer connect to what is on the other side of the boundary. Just as importantly, that project is challenged and supplemented in contemporary China by fundamentally different ways of thinking about the boundary itself: the ambiguous and

\footnotetext{
${ }^{15}$ This is the topic of a book currently in the prepublication process at Cambridge University Press, written by C. Julia Huang and the authors of this article, with Lizhu Fan. It is tentatively titled The Social Life of Goodness: Religious Philanthropy in Chinese Societies.

${ }^{16} \mathrm{We}$ are drawing here in part on the analysis in Seligman and Weller (2012).
} 
mediated boundary of Chen's monkey demon, and the defining difference of Liu's ghosts. Both of these offer alternatives to the absolute rift between good and evil that the dominant narrative suggests. We cannot reduce morality to a simple function of political economy, since here we have people in largely similar positions drawing on different moralities. ${ }^{17}$ Our cases demonstrate a continuation of multiple moral possibilities instead of the hegemony of just one. These potentially alternative moralities, as the monkey demon said, are "only a little bit weaker" than the dominant discourse, and show every sign of staying around to fight again. Allowing room for evil may be the only way to be moral.

\section{Acknowledgments}

We are grateful to the anthropologists Bai Li and Yang Der-Ruey for their help making fieldwork connections. We also want to thank participants in sessions at the American Anthropological Association meetings and at Harvard University's Fairbank Center for their helpful feedback. We are especially grateful to Charles Lindholm, Joel Robbins, and several anonymous readers for their very generous comments on earlier drafts. Finally, we thank the Harvard-Yenching Institute, whose fellowship to Keping Wu allowed us to collaborate on the writing in person.

\section{List of References}

Arendt, Hannah. 2006. Eichmann in Jerusalem: A Report on the Banality of Evil. New York: Penguin Classics.

Changzhou Shi Wenming Ban 常州市文明办 [Changzhou City Civilization Office]. 2013. Daode gushi (er) 道德故事(二) [Morality stories, vol. 2]. Changzhou: n.p.

Chen, Xingqiao 陈星桥. 1999. Fojiao Qigong yu Falun Gong 佛教气功与法轮功 [Buddhist Qigong and Falun Gong]. Beijing: Zongjiao wenhua chubanshe.

Clough, Paul, and Jon P. Mitchell, eds. 2001. Powers of Good and Evil: Social Transformation and Popular Belief. New York: Berghahn Books.

Douglas, Mary. 1966. Purity and Danger: Concepts of Pollution and Taboo. London: Routledge \& Kegan Paul.

Fei Xiaotong. 1992. From the Soil: The Foundations of Chinese Society. Translated by Gary G. Hamilton and Wang Zheng. Berkeley: University of California Press.

Freud, Sigmund. 1962. Civilization and Its Discontents. Translated by James Strachey. New York: W.W. Norton.

Geschiere, Peter. 1997. The Modernity of Witchcraft: Politics and the Occult in Postcolonial Africa. Charlottesville: University of Virginia Press.

Guo, QiTaO. 2003. Exorcism and Money: The Symbolic World of the Five-Fury Spirits in Late Imperial China. Berkeley: Institute of East Asian Studies.

${ }^{17}$ This is in contrast to the approach favored by many of the essays collected in Clough and Mitchell (2001). 
Harris, Olivia. 2006. "The Eternal Return of Conversion: Christianity as a Contested Domain in Highland Bolivia." In The Anthropology of Christianity, ed. Fenella Cannell, 51-76. Durham, N.C.: Duke University Press.

Inouye, Melissa. 2011. "Miraculous Mundane: The True Jesus Church and Chinese Christianity in the Twentieth Century." PhD diss., Harvard University.

Kang, XIAofer. 2005. The Cult of the Fox: Power, Gender, and Popular Religion in Late Imperial and Modern China. New York: Columbia University Press.

Kunn, Philip A. 1992. Soulstealers: The Chinese Sorcery Scare of 1768. Cambridge, Mass.: Harvard University Press.

Laidlaw, James. 2014. The Subject of Virtue: An Anthropology of Ethics and Freedom. Cambridge: Cambridge University Press.

Lee, Haiyan. 2007. Revolution of the Heart: A Genealogy of Love in China, 1900-1950. Stanford, Calif.: Stanford University Press.

Lian, XI. 2010. Redeemed by Fire: The Rise of Popular Christianity in Modern China. New Haven, Conn.: Yale University Press.

Macfarlane, Alan. 1985. “The Root of All Evil.” In The Anthropology of Evil, ed. David Parkin, 57-76. Oxford: Blackwell.

Meyer, Birgit. 1999. Translating the Devil: Religion and Modernity among the Ewe in Ghana. Trenton, N.J.: Africa World Press.

Отto, Rudolf. 1958. The Idea of the Holy. Translated by John W. Harvey. 2nd ed. New York: Oxford University Press.

Puett, Michael. 2010. "Ritualization as Domestication: Ritual Theory from Classical China." In Ritual Dynamics and the Science of Ritual, Vol. 1: Grammars and Morphologies of Ritual Practices in Asia, ed. Axel Michaels, 365-76. Wiesbaden: Harrassowitz Verlag.

Robbins, Joel. 2004. Becoming Sinners: Christianity and Moral Torment in a Papua New Guinea Society. Berkeley: University of California Press.

_ 2007. "Between Reproduction and Freedom: Morality, Value, and Radical Cultural Change.” Ethnos 72(3):293-314.

Seligman, Adam B., and Robert P. Weller. 2012. Rethinking Pluralism: Ritual, Experience, and Ambiguity. New York: Oxford University Press.

Shahar, Meir. 1992. "The Lingyin Si Monkey Disciples and the Origins of Sun Wukong." Harvard Journal of Asiatic Studies 52(1):193-224.

Shahar, Meir, and Robert P. Weller. 1996. Unruly Gods: Divinity and Society in China. Honolulu: University of Hawai i Press.

Szonyi, Michael. 1997. "The Illusion of Standardizing the Gods: The Cult of the Five Emperors in Late Imperial China." Journal of Asian Studies 56(1):113-35.

Taussig, Michael T. 1980. The Devil and Commodity Fetishism in South America. Chapel Hill: University of North Carolina Press.

von Glahn, Richard. 2004. The Sinister Way: The Divine and the Demonic in Chinese Religious Culture. Berkeley: University of California Press.

WANG ZuOAN 王作安. 2010. Zhongguo zongjiao wenti he zongjiao zhengce 中国宗教问题和宗 教政策 [Religious problems and religious policies in China]. Beijing: Religious Culture Publishing House.

Weller, Robert P. 1994. Resistance, Chaos, and Control in China: Taiping Rebels, Taiwanese Ghosts, and Tiananmen. Seattle: University of Washington Press.

Wielander, Gerda. 2013. Christian Values in Communist China. New York: Routledge. 
XI CHUAN 西川. 1999. “Ying de huayu” 鹰的话语 [What the eagle says]. Xi Chuan zhongyao chang shi 西川重要长诗 [Xi Chuan’s important long poetry], Baidu, July 19, 2006. http://tieba.baidu.com/p/115652146 (accessed October 30, 2016).

YAn, YunXiang. 2009. “The Good Samaritan's New Trouble: A Study of the Changing Moral Landscape in Contemporary China." Social Anthropology 17(1):9-24. . 2011a. "The Changing Moral Landscape." In Deep China: The Moral Life of the Person, by Arthur Kleinman, Yunxiang Yan, Jing Jun, Sing Lee, Everett Zhang, Pan Tianshu, Wu Fei, and Guo Jinhua, 36-77. Berkeley: University of California Press.

2011b. "How Far Away Can We Move from Durkheim? - Reflections on the New Anthropology of Morality." Anthropology of This Century 2 (October), http://aotcpress.com/articles/move-durkheim-reflections-anthropology-morality/ (accessed October 25, 2016).

YE XIAOWEN 叶小文. 2007. Zongjiao wenti: Zenmo kan, zenmo ban 宗教问题: 怎么看怎么办 [Religious questions: How to view them and how to deal with them]. Beijing: Religious Culture Publishing House. 